\title{
Dynamic Impact of Government Expenditure and Debt Policy Instruments on Agricultural Growth in Nigeria
}

\author{
Alexander Ibu Ochalibe, Federal University of Agriculture, Makurdi, Nigeria \\ Miriam Sewese Apeverga, Federal University of Agriculture, Makurdi, Nigeria \\ Ejiofor Emmanuel Omeje, University of Nigeria, Nsukka, Nigeria
}

\begin{abstract}
This research examined the impact of government expenditure and debt policy instruments on agricultural growth in Nigeria for the period 1980-2018. Findings revealed that, for every billion rise in aggregate government expenditure, agricultural growth significantly increased by $1.66 \%$. Additionally, per capita income and inflation were significant determinants of agricultural growth. However, the response of agricultural growth to increased debt was inelastic with a coefficient of -0.3152 . Thus, macroeconomic policy instruments dynamics impacted agricultural growth. It recommended increased government expenditure to agricultural sector, education, investing in human capital development through budgetary allocations and intervention funds for increased growth while policymakers should desist from increasing the debt profile as it gave less than proportionate effect on agricultural growth with negative consequences on the Nigerian economy.
\end{abstract}

\section{KEYWORDS}

Agricultural Growth, Debt, Government Expenditure, Policy Instruments

\section{INTRODUCTION}

To attain agricultural sector goals, several policies were formulated and implemented after Nigeria's independence. Some macroeconomic and sectoral policies implemented from 1970 to 1985 promoted growth with some shortcomings. According to Dayo, Ephraim, John and Omobowale (2009) government policies however led to the provision of many farm inputs and services which helped in the production, processing, and marketing of farm commodities (Chimobi and Uche, 2010). The need to correct some shortcomings of policy outcomes in Nigeria led to adoption of the Structural Adjustment Programme (SAP) of 1986. After SAP was introduced, there was general improvement in agricultural production and external trade from 1986 to 1989. Thereafter, growth indices of agricultural production fluctuated between stagnation and decline, a situation blamed mainly on policy reversals and inconsistencies. Government expenditure is a policy instrument targeted at influencing the level of production. Spending in agriculture is one of the most important government instruments for promoting economic growth (Sanyal, 2010; Fan et al, 2008; Ikpi, 1995). Over the years, spending in agriculture decreased and the GDP contribution from agriculture gradually declined in the 70's to 48\% and it continues to decline to $20 \%$ and $19 \%$ in 2005 (Everett et al., 2010). According to Isedu (2002),

DOI: $10.4018 /$ JTA.285571

This article published as an Open Access article distributed under the terms of the Creative Commons Attribution License (http://creativecommons.org/licenses/by/4.0/) which permits unrestricted use, distribution, and production in any medium, provided the author of the original work and original publication source are properly credited. 
one way capital expenditure impacts economic growth is the creation of employment and causes economic growth through the re-allocation of resources to every sector of the economy. Aregbeyen (2007) found a positive and significant relationship between capital expenditure and economic growth but a negative relationship between recurrent expenditure and economic growth but research on the impact of aggregate government expenditure on agricultural growth remain scanty in Nigeria.

According to Federal Ministry of Agriculture and Rural Development, FMARD (2016) the vision of the current administration in Nigeria for agriculture is to build an economy capable of delivering sustained prosperity by meeting domestic food security goals, generating exports, and supporting sustainable income and job growth. In line with this, its policy objectives for the period 2016-2020 aim at: Growing the integrated agriculture sector at $100 \%$ to $200 \%$ the average of Nigerian GDP. This implies that assuming a GDP growth of 7\%, agriculture would aim to achieve 7\% - 14\% growth. Accordingly, the target for agriculture's share of GDP is $23 \%$ for the period; agriculture's share of the labor force: $70 \%$; crop production: $85 \%$; livestock and other non-crop: 15\%; agriculture's share of non-oil exports earnings: 75\% and agriculture's share of federal budget: $2.0 \%$. Although FMARD (2016) also reported that agricultural sector recorded a historical growth of between $3 \%$ - $6 \%$ per annum in 2011 - 2015, agricultural export crops had been on the decline since the late 1970s (Adubi, 1999). However, inadequate funding of the agricultural sector has been re-echoed by several experts as an obstacle to increased agricultural growth (Ammani and Aliyu, 2012; Agbonkhese and Asekome, 2014; CBN, 2013). Fan and Rao (2003) showed that government spending on agriculture has provided a strong contribution to economic growth in Asia. Amassoma, Nwosa, and Ajisafe (2011); Abu and Usman (2010) showed that spending on rural infrastructure and productivity enhancing investments in agricultural export crops and livestock has the most promise for growth in income and food consumption in Africa. According to Obansa and Maduekwe (2013) agriculture remains the mainstay of the economy given its share in employment. Yet, in the majority of developing countries, public expenditure in agriculture is stagnant or declining, and this is reflected in poor contribution of agricultural outputs to GDP (Hartwich et al., 2010; World Bank, 2007; Olomola, 2007; Manyong et al., 2005). Still, most agricultural based economies depend on agriculture for a large share of their foreign exchange as exemplified by tobacco exports in Malawi and labor intensive nontraditional exports in Kenya and Senegal (World Bank, 2008).

Fiscal instruments of government include public expenditure, public debt, taxes, investment and trade openness among others. Fiscal policy consists of managing the national budget and its financing so as to influence economic activity (Agu etal, 2014). This entails the expansion or contraction of government expenditures related to specific government programs such as building roads or infrastructure, military expenditures and social welfare programs. It also includes the raising of taxes to finance government expenditures and the raising of debt (treasuries in the U.S.) to bridge the gap (budget deficit) between revenues (tax receipts) and expenditures related to the implementation of government programs (Akhanol et al., 2017). Raising taxes and reducing the budget deficit is deemed to be a restrictive fiscal policy as it would reduce aggregate demand and slow down GDP growth. Increasing the budget deficit and debt profile is considered an expansive fiscal policy that would increase aggregate demand and stimulate the economy (Awoderu et al., 2016; Aregbeyen, 2017 and Chete, and Taiwo, 2007). However the negative effect of an increase in public debt on future GDP (or GNP) can be amplified by the presence of discretionary taxes (FAO, 2004). Government expenditure is usually targeted at influencing the level of production directly: for example, by trying to create more incentives for firms to innovate indirectly it affects the prices of goods and services. Increased investment will attract the demand for labor and stimulate productivity hence growth in agriculture. Low government expenditure may increase the cost of production such as equipments and implements costs hence high cost of goods. These costs may also arise from increase in private expenditures on public facilities that could have been provided by the state. Increased public expenditure may well mean that the basic infrastructures e.g. roads, electricity, irrigation and drainage as well as Research $\&$ Development among others will improved which may decrease unemployment although it may 
be associated with inflation arising from higher increased income ceteris paribus. The reverse is also true. It can be argued that public expenditure may lead to crowding out. But when basic infrastructures are involved government expenditure cannot be neglected though it may result in budget deficit with increased debt. Undoubtedly, higher debt is known to retard growth. In the same vein increased spending that allow for excess supply of money may result in inflation. Also, it has a persistent tendency for higher prices and higher money wages. Increased wage rate means more income and has the tendency to increase productivity, hence increased agricultural growth thereby expanding agriculture share in total national income. This will largely depend on the income elasticity of production.

Government expenditure which represents one of the most important policy instruments through which government directs the performance of the economy in general and the agricultural sector in particular remains low in Nigeria. Burkina Faso invests 10\% and most Asian nations invest 16\% of their national budget into the agricultural sector (United Nation, 2016). Unfortunately, Nigeria invests less than $2 \%$ of her national budget into agriculture annually (Aregbeyen, 2017). Increased expenditure on agricultural sector is needed to purchase land, construct buildings, acquire machinery and equipment, and hire labor, carry out research and development etc (Obansa and Maduekwe, 2013). Still, agriculture expenditure as a percentage of agricultural GDP remained at relatively similar levels in Africa (5.4 - 7.4 per cent), while in Asia, expenditure as a percentage of agricultural GDP was much higher (8.5 - 10.5 per cent) than in Africa (Eboh, Oduh, and Ujah, 2012; Eze et al., 2010; Abu and Usman, 2010; Nkonya et al., 2010; UNDP, 2010). In Nigeria, the capital expenditure on agriculture declined from $6.2 \%$ of total capital expenditure by the Federal Government in 1973 to $4.0 \%$ in 1985. The expenditure of state government or sub-nationals followed similar pattern (Egwu and Akubilo, 2007). This low and declining budgetary allocation may be another good reason why Nigeria has not attained sustainable growth in agriculture and still remain a net food import country. Additionally, in spite of the potential high economic rates of return to investments in rural infrastructure, and significant deficiencies of rural infrastructure in most developing countries, neither national governments nor international aid agencies seem to prioritize policy initiatives targeted at the construction of new infrastructure and maintenance of existing infrastructure (UN, 2016). This raises the question as to whether government goal of increased growth is still achievable and whether the government of Nigeria has utilized expenditure and debt as a policy instruments such that revenue generation is increased through the productivity of resources to meet its policy objectives for agricultural growth in the face of dwindling oil revenue. Furthermore, despite the relevance of the issues raised, empirical research on combined impact of expenditure and debt policy instruments on agricultural growth is scanty with less emphasis on indirect policy outcomes. Most studies (e.g. Maskus, 1986; Ajayi 1995; Osagie, 1985 and Calvo and Reinhart, 2002 etc) concentrated on agricultural specific instruments e.g. agricultural subsidies, taxes and tariff, quotas, irrigation policies etc without looking at the impact of macroeconomic policy instrument like general level of debt and aggregate expenditure on agricultural growth which this study seek to achieve.

\section{LITERATURE REVIEW}

Although classical economist opined that government spending and involvement can retard a nation economic growth by increasing the public sector and decreasing the private sector growing out of proportion but Keynesian economics relies on government spending to jump start a nation's economic growth during sluggish economic down. Previous study of impact of government expenditures on agriculture provides mixed results. Fan and Rao (2003) showed that government spending on agriculture has provided a strong contribution to economic growth in Asia. Amassoma, Nwosa, and Ajisafe (2011); According to Obansa and Maduekwe (2013) public expenditure in majority of developing countries to agriculture is stagnant or declining, and this is reflected in poor contribution of agricultural outputs to GDP (Hartwich et al., 2010; World Bank, 2007; Olomola, 2007; Manyong 
et al., 2005). Isedu (2002) posits that capital expenditure reduce unemployment. Raising taxes and reducing the budget deficit is deemed to be a restrictive fiscal policy as it would reduce aggregate demand and slow down GDP growth. Akpan (2005) opined that no significant relationship exists among some components of government expenditures and economic growth in Nigeria. Aregbeyen (2017) however found a positive and significant relationship between capital expenditure and economic growth but a negative relationship between recurrent expenditure and economic growth. Modebe, et al. (2012) examined the impact of government capital and recurrent expenditure on the Nigerian economy from 1987 to 2010 using three variables multiple regression model. The findings reveal that while capital expenditure had a negative and non-significant impact on the economy, recurrent expenditure had a positive and non-significant impact on the same economy. Amassoma, Nwosa, and Ajisafe (2011) also used the error correction model to study the impact of government expenditure disaggregated into agriculture, education, health, transport, and communication on the Nigerian economy with data from 1970 to 2010. They concluded that only agriculture expenditure had a significant impact on the economy. Others had insignificant influence on economic growth.

Oluwatobi and Ogunrinola (2011) found a positive relationship between recurrent expenditure on human capital and level of real output but a negative relationship between capital expenditure and the level of real output. Ogujiuba and Adeniyi (2004) result showed the existence of significant positive relationship between economic growth and recurrent expenditure on education, while capital expenditure was wrongly signed and not significant in its contributions. However, Fajingbensi and Odusola (1999) found the contribution of recurrent expenditure to growth insignificant. According to Olatunji and Oloye (2015) government of most developing countries appear to increase their expenditures in critical sectors of their economies. However there was a rapid decline in agricultural production with large food supply gaps (Sanyal and Babu, 2010) with attendant rapid increase in food imports from $7.7 \%$ in 1970 to $10.3 \%$ in 1979 (Ugwu et al., 2014). According to the FAO (2016), the rates of investment per worker in agriculture have been declining or have stagnated for three decades in Africa and the average share of agriculture in public expenditure fell from 4.5 percent in 2001 to 2.7 percent in 2015, far from the 10 percent target set by the Maputo declaration. During the same period, the share of commercial credit devoted to agriculture in Africa dropped by 3.6 percent to an average of 2.8 percent, whereas the global average is 5.8 percent (FAO, 2016).From the review above it can be deducted that fiscal policy can temporarily raise or lower national income or counteract macroeconomic disturbances that would otherwise influence national output. For example decrease in education resulting from lower education expenditure increase poverty decreases per capital income and worsen sustainability (UNEP, 2011). Reinhart and Rogoff (2011) showed that high levels of debt are negatively correlated with economic growth, but that there is a link between debt and growth when public debt is below 90 percent of GDP..Cecchetti, Mohanty and Zampolli (2011) considering the question "When does debt go from good to bad?" and using dataset that included the level of government, non-financial corporate and household debt in 18 OECD countries from 1980 to 2010 showed that beyond a certain level, debt is a drag on growth. For government debt, the threshold was around $85 \%$ of GDP. The immediate implication is that countries with high debt must act quickly and decisively to address their fiscal problems. The longer-term lesson is that, to build the fiscal buffer required to address extraordinary events, governments should keep debt well below the estimated thresholds. They also showed that when corporate debt goes beyond $90 \%$ of GDP, it becomes a drag on growth.

In Nigeria agricultural sector provides a significant proportion of the Nigeria's labor force; and indirectly it provides important linkages with the rest of the economy (IFAD, 2010; Soludo, 2009; Issern and Pellegrini, 2009, World Bank, 2008; Onu and Okunmadewa, 2007; Chete and Taiwo, 2007; Olayide et al., 1980). Investment plays a dual role in economic growth. It is a component of aggregate demand and thus helps determine the level of actual output. The quality of investment policies directly influences the decisions of all investors (Davood and Mohammed, 2013) in all sectors of the economy. It is also probably the major determinant of potential output, since investment both increases 
the capital stock and also leads to the development of new technology. Therefore, the symptoms of macroeconomic instability resulting unfavourable policy instruments may become manifest in a number of ways: budget deficits will rise, current account deficits increase, exchange rate overvaluation occurs and inflation grows. High inflation directly erodes the real value of domestic assets and increases the cost of inputs for agricultural activities, stimulating firms to withhold their investment. Under such scenario the agricultural growth rate will be low. The reverse is also true. Increasing employment and incomes in agriculture stimulates demand for non-agricultural goods and services, providing a boost to non-farm rural incomes as well. While high prices of agricultural produce could spur growth in the sector it may produce negative effect on farmers in general. It is generally agreed in the literature that investment stimulates growth within a market economy' as a result private sector investment no doubt remains the engine of growth with the public sector providing the enabling environment and spending in agriculture is likely to be one of the most important government policy instruments for promoting agricultural growth especially at this stage of development.

\subsection{Theoretical Framework}

There are several potential policy instruments that separately or together can contribute to the stated objectives, and the task of agricultural policy analysis is to assess the advantages and disadvantages - the benefits and costs - of the alternative policy instruments available (Ellis, 1996). On theoretical grounds, Chinery (1958) suggested the following set of equations:

Net domestic saving: $S=\alpha_{1} W+\alpha_{2} R+T-G$

Taxation: $T=t$

Income distribution: $W=w(R+W)$

Where

$\mathrm{W}=$ Disposable wage income

$\mathrm{R}=$ Disposable non-wage income

$\mathrm{T}=$ Taxes

$\mathrm{G}=$ Government current expenditure

$\mathrm{t}=$ Tax rate

$\mathrm{w}=$ Share of wages in disposable income

The above formulation shows the several effects of government policy on savings by using three instruments: government expenditure $(\mathrm{G})$, the tax rate $(\mathrm{t})$, and the share of wages $(\mathrm{w})$ assuming information is not available to estimate the parameters in the savings and tax functions, the formulation becomes:

$S=\alpha^{*} Y-G$

and finally to

$S=\alpha Y$

In the last form, $\alpha$ reflects all the government policies that influence the rate of savings. If savings in equation (5) is replaced with the variable agricultural growth then agricultural growth (Ag) 
becomes a function of macroeconomic policy instruments. A similar range of alternatives could be shown for other instrument variables which are less directly connected to the actions of the government. Since the economic structure may change rapidly in an underdeveloped economy like Nigeria, according to Chenery this aggregate model, can be used to study variations from the initial solution. Therefore the endogenous growth theory is encapsulated in the next section

\subsection{Endogenous Growth Theory}

According to Agbonkhese and Asekome (2014) endogenous growth theory highlighted the fact that if productivity was to increase, the labor force must continuously be provided with more resources. Therefore, growth was driven by accumulation of the factors of production, while accumulation of factors in turn was the result of investment in the private sector. This implied that the only way a government can affect economic growth, at least in the long run, was via its impact on investment expenditures in capital, education and research and development. Reduction of growth in these models occurred when incentives to invest and increased expenditure are taking away to save an accumulate capital (Folster and Henrekson, 1997). The endogenous growth theories believe that the sources of economic growth are endogenous. Until recently endogenous growth theories have constructed a model in order to analytically illustrate the mechanism by which savings can affect economic growth. Among them, Agosin and Meyer (2000) presented a model in which both capital accumulation and growth are endogenously determined. In order to implement their analysis, we consider the simplest endogenous growth model of production function utilized by Pingali (2006), in which the output (Y) is produced during the period $(\mathrm{t})$ by one factor, which is capital $(\mathrm{Kt})$ :

$$
Y=\mathrm{f}(\mathrm{Kt}
$$

Let us assume that the population is stationary, and that the economy only produces one good which can be consumed or invested. If invested, it could depreciate at the rate $\delta$ per period. The investor can sell the production of the time $(\mathrm{t}+1)$ at the time $(\mathrm{t})$. If depreciation of the price occurs, then the investor will lose. This is what the model refers to as $\delta$. thus gross investment, according to Pingali (2006) can be expressed as follows:

$$
l_{t}=k_{t+1}-(1-\delta) k_{t}
$$

In a closed economy with no government, capital market equilibrium requires that gross savings $\left(S_{t}\right)$ equal investment $\left(I_{t}\right)$ i.e. $S_{t}=I_{t}$. it is conventional to assume that a proportion $(1-\varphi)$ of flow savings is lost in the process (Agbonkhese and Asekome 2014). In this way, the only part of saving that can be allocated to investment is: $\varphi S_{t}$ thus : $\varphi S_{t}=I_{t}$

$$
\begin{aligned}
& g_{t+1}=\frac{Y_{t+1}}{Y_{t}}-1=\frac{k_{t+1}}{k_{t}}-1 \\
& k_{t+1}=I_{t}+(1-\delta) K_{t}
\end{aligned}
$$

By replacing $\mathrm{Kt}+1$ with its value, we have 
$g_{t+1}=\frac{I_{t}+(1-\delta) K_{t}}{K_{t}}$

$g=A \frac{I_{t}}{Y_{t}}-\delta \leftrightarrow g=A \varphi S-\delta$

The rate of growth $(\mathrm{g})$ is equal to the product of the marginal productivity of capital (A), the rate of saving (s) and the proportion of savings funnelled to investment $(\varphi)$ minus $\delta$. From this model, resources mean physical capital, human capital and knowledge capital (technology) and one can then conclude that: firstly, unlike the Solow model, both saving and productivity of capital affect positively long term economic growth. Secondly, the remaining fraction $(1-\varphi)$ can be considered as tax imposed by government in the form of reserve requirements, transaction taxes etcetera (Borenszetein, Degregorio and Lee, 1998). Thus, if one can reduce this leakage of resources, that is, raise the saving rate in equation (11), it also increases the growth rate (g). Since endogenous growth rate is driven by the accumulation of factors of production-land, labor and capital (the basic economic resources) while accumulation in turn is as a result of investment. Arguably, government expenditure policy instrument can potentially impact growth in agriculture and enhance. For instance, while capital expenditure gave rise to recurrent expenditure in most cases through the operational and maintenance costs of completed capital projects, the amount available for investment is a function of not only the size of revenue but also the amount that goes annually into the running of government (Agbonkhese and Asekome, 2014).

\section{METHODS AND DATA}

The study utilized secondary source of data on policy instruments and agricultural growth. Data on debt, taxes, general tariff, Government expenditures, and education expenditures were obtained from, World Bank. Data for the study were analyzed through the application of both descriptive and inferential statistical tools. Unit root test (ADF) was adopted as a pre-estimation technique. The study adopts a survey design. Unit Root Test, and Granger Causality Pre-estimation tests were carried out to avoid spurious parameters. After the estimation, a diagnostic test of misspecification, robustness/ heteroscedasticity, autocorrelation and multicollinearity were carried out to assess the validity of the empirical model. Trend analysis and distributed lag model in conjunction with Two Stage least Squares (2SLS) as well the use of Difference-in Differences Estimation Model (DID) were utilised in analysis to achieve the specified objectives. Endogeneity test was carried out to ascertain the presence of endogeneity to justify the use of 2SLS.

\subsection{Model Specification}

\subsection{Unit Root Test-Augmented Dickey-Fuller (ADF) Model}

The Augmented Dickey-Fuller (ADF) test consists of estimating the following regression:

$$
\Delta y_{t}=x_{t}^{\prime} \beta+\delta y_{t-1}+\sum_{i=1}^{p} \Delta y_{t-p}+\varepsilon_{t}
$$

Where $\Delta=$ difference operator; $\mathrm{y}=$ vector of the $\mathrm{n}$ variables (i.e. interest rate, exchange rate, government expenditure, etc); $x=$ optional exogenous regressors which may consists of constant 
or a constant and trend; $p=$ number of lags; $\varepsilon_{t}=$ error term. Null hypothesis: $\mathrm{H}_{\mathrm{o}}$ : $\delta=0$ (i.e., there is a unit root or the time series is non-stationary, or it has a stochastic trend).Alternative hypothesis: $\mathrm{H}_{1}: \delta<0$ (i.e., the time series is stationary, possibly around a deterministic trend). If the ADF statistic is greater than the critical value at $5 \%$ level of significance, that means the series is stationary, if the ADF statistic is less than the critical value at $5 \%$ level of significance, it means the series is non-stationary.

\subsection{Trend Analysis of Agricultural Growth: Growth Trend Model}

$\mathrm{Yt}=\mathrm{Y}_{0}(1+\mathrm{r}) \mathrm{t}$

Where $\mathrm{Y}_{\mathrm{t}}=$ rate of agricultural growth; $\mathrm{Y}_{0}=$ rate of agricultural growth in a base year; $\mathrm{r}=$ compound rate of growth of $\mathrm{Y} ; \mathrm{t}=$ time in chronological years in natural log form we have

$\operatorname{In} Y_{t}=\ln Y_{0}+\operatorname{tln}(1+r$

Substituting $\operatorname{InY}_{0}$ with $\beta_{1}$ and $\operatorname{Ln}(1+\mathrm{r})$ with $\beta_{2}$, we re-write equation as

$\operatorname{InY}_{\mathrm{t}}=\beta_{1}+\beta_{2} \mathrm{t}$

Adding the disturbance term to equation we obtain

$\operatorname{InY}_{\mathrm{t}}=\beta_{1}+\beta_{2} \mathrm{t}+\mu \mathrm{t}$

Equation (16) is a growth rate model developed for this study. A semi-log growth model was developed for this study instead of a linear trend model because the point of interest in this study is both absolute and relative change in the parameters of interest. The most important parameter in equation (16) is the coefficient $\beta 2$. This is the coefficient of the slope which measures the constant proportional or relative change in $\mathrm{Y}$ for a given absolute change in the value of the regressor, $\mathrm{t}$. Multiplying $\beta 2$ by 100 gives the instantaneous growth rate at a point in time.

$\operatorname{IGR}=\beta_{2} \times 100$

Where: $\mathrm{IGR}=$ Instantaneous growth rate

According to Gujarati (2009) $\beta_{2}$ is the least-square estimate of the coefficient of the slope $\beta$ 2 , then taking the anti-log of $\beta_{2}$ and subtracting 1 from it and then multiplying the difference by 100 give the compound growth rate (CGR) over a period of time:

$\mathrm{CGR}=\left[\operatorname{antilog} \beta_{2}-1\right] \times 100$

If the coefficient $\beta_{2}$ is positive and statistically significant or negative and statistically significant there is acceleration or deceleration in growth process respectively. If $\beta_{2}$ is not statistically significant there is stagnation in the growth process. 


\subsubsection{Dynamic Model: Finite Distributed Model}

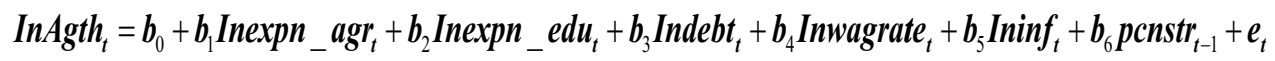

Where $I n=$ natural logarithm; $b_{0}-b_{6}=$ parameters to be estimated; Agrth $=$ is the annual aggregate agricultural contribution to GDP in millions of naira; expn_agric $=$ expenditure on agriculture measured as share of agriculture in the government expenditure outlay in millons of naira; expn_edu $=$ expenditure on education measured as share of education in annual budget in millions of naira; $d e b t=$ external debt measured as the external debt stocks, total (current US\$) to gross domestic product. It is the sum of public, publicly guaranteed, and private nonguaranteed long-term debt, short-term debt, and use of IMF credit; wage_rate= wage rate, control variable approximated by per capita income; infl $=$ inflation rate measured as the percentage change in the general price of all goods and services(\%) and pcnstr $_{t-1}=$ lag of policy instruments; $e_{t}=$ is a stochastic error term that satisfies the normal classical regression assumptions. It is expected that increased in public expenditures and wage rate will yield aggregate agricultural growth ceteris paribus.

\section{RESULTS}

\subsection{Pre-Estimation Test: Unit Root Test}

In empirical research on time series data it is necessary to conduct a Unit Root test for stationarity or non-stationarity. Table 1 reports the Unit root test results for tax rate (tax); education expenditure US\$) (expn_edu); expenditure on Agriculture (current US\$) (expn_agric); and Annual inflation rate-CPI for all items $\left(N_{-} f l a\right)$.

Table 1 indicates that only few of the series are trending and potential I(1) processes. The number of lags $(\mathrm{k})$ was determined based on the Akaike Information Criterion. A variable is said to be stationary when it has no unit root which is denoted in literature as 1(0). A non-stationary variable can have one or more unit root and it is denoted by $\mathrm{I}(\mathrm{d}), \mathrm{d}$ is the number of unit root that the variable possesses and by implication, the number of times that the variable must be differenced in order to make it stationary. From Table 1, most the variables are stationary at order I (0) respectively except external debt. This is an indication that while external debt, were stationary at first difference the rest of the variables were stationary at their respective level. Therefore the null hypothesis of nonstationarity is rejected at $5 \%$ level of significance.

Table 1. Results of aurgumented Dickfuller Unit root test

\begin{tabular}{|l|l|l|l|l|l|}
\hline \multicolumn{1}{|c|}{ Variable } & \multicolumn{1}{|c|}{ ADF Statistics Z(t) } & $\begin{array}{c}\text { Mackinnon } \\
\text { critical } \\
\text { value@ 5\% }\end{array}$ & $\begin{array}{c}\text { differenced } \\
\text { level }\end{array}$ & P-value Z(t) & \multicolumn{1}{|c|}{ Remarks } \\
\hline Agrth & -3.668 & -1.688 & $1(0)$ & $0.003^{* * *}$ & Stationary \\
\hline Tax & -5.257 & -1.688 & $1(0)$ & $0.000^{* * *}$ & Stationary \\
\hline expn_edu & -1.342 & -1.688 & $1(1)$ & $0.094^{*}$ & Stationary \\
\hline expn_agric & -2.503 & -1.688 & $1(0)$ & $0.008^{* * *}$ & Stationary \\
\hline ext_debt & -3.668 & -1.688 & $1(1)$ & $0.001^{* * *}$ & Stationary \\
\hline N_fla & -5.070 & -1.688 & $1(0)$ & $0.000^{* * *}$ & Stationary \\
\hline
\end{tabular}

Source: Computed from secondary data, 2018.Note: ${ }^{* *}$ significant at $1 \%$; ** significant at $5 \%$ and * significant at $10 \%$. 


\subsection{Granger Causality Test Between Policy Instruments and Agricultural Growth}

The result of the pair wise granger causality test between policy instruments and agricultural growth is presented in Table 2 .

Table 2. Granger pair wise causality test between policy instruments and agricultural growth

\begin{tabular}{|l|l|l|l|l|}
\hline \multicolumn{1}{|c|}{ Null Hypothesis } & Df & \multicolumn{1}{|c|}{ Chi2-Statistics } & \multicolumn{1}{|c|}{ Probability } & \multicolumn{1}{c|}{ Decision } \\
\hline Agrth does not granger cause lnexp & 3 & 44.074 & $0.000^{* * *}$ & Rejected \\
\hline Inexp does not granger cause agrth & 3 & 21.937 & $0.000^{* * *}$ & Rejected \\
\hline debt does not granger cause agrth & 3 & 8.132 & $0.040^{* *}$ & Rejected \\
\hline Agrth does not granger cause debt & 3 & 1.256 & 0.740 & Not rejected \\
\hline wage_rate does not granger cause agrth & 3 & 7.602 & $0.055^{*}$ & Rejected \\
\hline agrth does not granger cause wage_rate & 3 & 0.755 & 0.860 & Not rejected \\
\hline
\end{tabular}

Source: Computed from secondary data, 2018

Note: ${ }^{* * *}$ significant at $1 \% ;{ }^{* *}$ significant at $5 \%$ and ${ }^{*}$ significant at $10 \%$.

The result showed that there exist a bidirectional relationship between agrth and exp $(\mathrm{P}=0.000<0.01)$ and $(\mathrm{P}=0.000<0.01)$ respectively which imply that change in government expenditure policy instruments will affect agricultural growth just the same way a change in agricultural growth will influence policy instruments in Nigeria. While debt $(\mathrm{P}=0.040<0.05)$ and wage_rates $(\mathrm{P}=0.055>0.1)$ have a unidirectional relationship with agrth. Therefore the null hypothesis should be rejected while the alternative hypothesis should be accepted. The implication is that all the variables indicated are causes changes in agricultural growth in Nigeria.

\subsection{Instantaneous and Compound Growth Rate of Policy Instruments, Agricultural Growth Rate and Sustainability Indicators}

The result from trend analysis of agriculture output (agrth); expenditure on Agriculture (current US\$) (expn_agric); are presented in Table 3. From the table the trend of policy instrument showed that there was acceleration in the growth in most of the policy instruments but deceleration in money supply (mss) with no recorded stagnation during the period under review. The instantaneous growth rate (at a point in time) for agriculture $(\mathrm{P}=0.000<0.01)$ was $5.9 \%$. This means that the relative change in agricultural output with respect to absolute change in the trend variable was $5.9 \%$ while the compound (over the period under review) rate of growth amounted to $6.08 \%$. The implication is that there was a general improvement in the agricultural growth process in Nigeria during this period even though the growth may not be as expected. The result showed further that there was a deceleration in the index resource sustainability $(\mathrm{P}=0.068<0.1)$ during the period of study with instantaneous growth rate and compound growth rate of $-2.81 \%$ and $-2.84 \%$ respectively. There was acceleration in growth for with instantaneous and compound growth rate of expenditure to agriculture $(\mathrm{P}=0.000<0.01)$, external debt $(\mathrm{P}=0.082<0.1)$ with instantaneous and compound growth rate of $1.23 \%, 1.24 \%$ respectively.

Although efforts were made through the use of monetary and fiscal policies to improve macroeconomic stability and stimulate growth (Oluwatobi and Ogunrinola 2011) the growth rate of exchange rate and interest rate may well suggest failure of policy instruments application in this regard. The implication of the empirical results is that the targets sets by the government of Nigeria are not achievable since government has not utilized macroeconomic policy instruments such that revenue generation is increased through the productivity of resources to meet national policy objective towards agricultural growth and resource sustainability given the pressure on natural resources. The instantaneous growth rate for forest resources $(\mathrm{P}=0.008<0.01)$, arable land $(\mathrm{P}=0.47>0.01)$ and human 
capital $(\mathrm{P}=0.005<0.01)$ were $1.57 \%, 0.33 \%$ and $1.93 \%$ with a compound rate of growth of $-1.58 \%$, $0.34 \%$ and $-1.95 \%$ respectively. This means that the relative change in forest resources, arable land and human capital with respect to absolute change in the trend variable were $-1.57 \%, 0.333 \%$ and $1.93 \%$ respectively. Therefore there was a deceleration in forest resources and human capital while arable land was stagnant. The implication is that agricultural resources are not on a sustainable path and more effort may be required to enhance sustainability of this resources however this cannot concluded without further analysis.

\section{Table 3. Instantaneous and Compound Growth Rate}

\begin{tabular}{|l|l|l|l|}
\hline & \multicolumn{1}{|c|}{ Instantaneous growth rate\% } & \multicolumn{1}{c|}{ Compound growth rate\% } & \multicolumn{1}{c|}{ P-value } \\
\hline Agrth & 5.90 & 6.08 & $0.000^{* * * *}$ \\
\hline Inexpn_agric & 7.62 & 7.92 & $0.000^{* * * *}$ \\
\hline Inexdebt & 1.23 & 1.24 & $0.082^{*}$ \\
\hline
\end{tabular}

Source: Computed from secondary data, 2018

Note: ${ }^{* * *}$ significant at $1 \%$; ** significant at $5 \%$ and ${ }^{*}$ significant at $10 \%$.

\subsection{Impact of Expenditure Policy Instruments from Distributed Lag Model}

The coefficient of government expenditure (lnexpn_agric) policy instrument was about 1.05 with $(\mathrm{P}=0.000<0.01)$. This means that a percentage rise in expenditure policy instrument resulted in $1.05 \%$ increase on agricultural growth ceteris paribus. The implication is that increasing expenditure on agriculture will have positive impact on agricultural growth. The coefficient of debt (debt_gdp) policy instruments was -0.3152 with $(\mathrm{P}=0.019<0.05)$ and statistically significant at $5 \%$. This means that a percentage rise in debt policy instrument resulted in $-0.32 \%$ negative impact on agricultural growth ceteris paribus. This finding is in agreement with Reinhart and Rogoff (2011) who showed that high levels of debt are negatively correlated with economic growth, but that there is a link between debt and growth when public debt is below 90 percent of GDP. This perhaps suggests that beyond a certain level, debt is a drag on growth. For government debt, the threshold was around 85\% of GDP (CBN, 2018). Expenditure to education (lnexpn_edu) and wage rate (w_rate) as a controlled variables had coefficients of $5.2059(\mathrm{P}=0.012<0.05)$ and 14.860 respectively. The implication is that expenditure to education as well as increased wage will result in agricultural growth.

The coefficient of export tariff (exp_tarr) policy instrument was 3.273 and statistically significant at $1 \%$. This implies that a percentage rise in export tariff policy instrument resulted in $3.27 \%$ impact on agricultural growth ceteris paribus. The coefficient of import tarrif (imp_tarr) policy instrument was 2.95 and statistically significant at $1 \%$. This implies that a pecentage rise in import tariff policy instrument resulted in $2.95 \%$ impact on agricultural growth ceteris paribus. Besides protection or outright ban, export taxes and subsidies, a country can use import policy instrument to change the level of domestic production and industrialization. But recent report disclosed that Africa spends \$35.4 billion on food imports annually. Nigeria accounts for $\$ 11$ billion of this amount (UNCTAD, 2016).

It further shows that tariff policy instruments is central tool for trade policy with far-reaching effects, since is effectively linked with domestic prices and costs. In real terms, people produce goods and services if they find these activities rewarding. In producing for exports and import-competing goods and services, the import and export tariff plays a crucial role, as it also relates to domestic prices and costs (Sanyal \& Babu, 2010). Tariffs are thus a powerful mechanism to protect sectors that produce import substitutes, and are justified whenever world price level is objectively too low to warrant the right incentives to the agricultural production. 


\subsection{Result Estimates from 2SLS}

In order further to achieve objective II the study utilized both 2SLS, Table 4. The inclusion of endogenous regressors in a model biases an estimate of a regression coefficient on it toward zero. According to Wooldridge (2009) if there is simultaneity, recursive models are not consistent but the methods of two stage least squares (2SLS) and instrumental variables will give estimators that are consistent and efficient since government policy instruments are not utilized independently from the other. For instance government do not set spending and tax rates independently of what is happening in the economy. Government expenditure policy instrument equally has effect on agricultural growth just as agricultural growth through revenue from agricultural production. It was therefore suspected that both variables may be endogenous to the model which goes to show that they are jointly dependent. According to Ofanson (2007) growth in the economy causes public sector expenditures to expand and public expenditures are endogenous to economic development.

Table 4. Estimate economic policy instruments from distributed lag model

\begin{tabular}{|l|l|l|l|l|}
\hline \multicolumn{1}{|c|}{ Variables } & \multicolumn{1}{c|}{ B-Coefficient } & \multicolumn{1}{c|}{ Standard error } & \multicolumn{1}{c|}{ T-value } & \multicolumn{1}{c|}{ P-value } \\
\hline Inagrth_1 & 0.3833 & 0.14005 & 2.74 & $0.011^{* *}$ \\
\hline Inexpn_agric & 1.0461 & 0.21311 & 4.91 & $0.000^{* * *}$ \\
\hline Inexpn_edu & 5.2059 & 1.93044 & 2.7 & $0.012^{* *}$ \\
\hline Inexdebt_gdp & -0.3152 & 0.68972 & -2.46 & $0.019^{* *}$ \\
\hline Inw_rate & 1.4860 & 0.2011 & 7.39 & $0.000^{* * *}$ \\
\hline InImp_tarr & 2.9593 & 2.9232 & 5.01 & $0.000^{* * *}$ \\
\hline InExp_tarr & 3.2737 & 0.9635 & 3.40 & 0.002 . $^{* * *}$ \\
\hline _cons & -32.048 & 31.379 & -1.02 & $0.016^{* *}$ \\
\hline Number of obs & $=$ & 38 & & \\
\hline F(7, 27) & $=$ & 21.79 & & \\
\hline Prob > F & $=$ & 0.000 & & \\
\hline R-squared & $=$ & 0.8898 & & \\
\hline Adj R-squared & $=$ & 0.8489 & 1.1647 & \\
\hline Root MSE & $=$ & & & \\
\hline Not & & & & \\
\hline
\end{tabular}

Note: ${ }^{* * *}$ significant at $1 \% ;{ }^{* *}$ significant at $5 \%$ and ${ }^{*}$ significant at $10 \%$.

Source: Computed from secondary data, 2018

In general terms, past capital projects maintained plus new ones that will add to the economy are established in order to improve more on the economy. To correct for the endogeneity problem the Two Stage Least square (2SLS) regression model was estimated and presented in Table 4.

From Table 4, the key variable is the vhat3, the residual from the reduced form. Looking at the $\mathrm{t}$-statistics for the null hypothesis that its coefficient is zero with a p-value of 0.002 is a strong evidence of endogeneity of lnexpn_agric so the variable agricultural growth and expenditure to agriculture are jointly determined. The IV regression output reports Z-values because IV regression has properties that depend upon having large samples, and we know that in large samples the $t$-distribution converges to the standard normal $N(0,1)$ distribution, thus $t$-statistics become Z-statistics. In large samples it does not matter if critical values for tests come from one distribution or the other, but in smaller samples it can matter (Wooldridge, 2009). The additional output is the first-stage regressions. Stata also includes an option that will display the first stage (the reduced form) of two stage least squares (Table 5). 
Table 5. Two stage least square estimation test for endogeneity

\begin{tabular}{|l|l|l|l|l|}
\hline \multicolumn{1}{|c|}{ Variables } & \multicolumn{1}{c|}{ B-Coefficient } & \multicolumn{1}{c|}{ Standard error } & \multicolumn{1}{c|}{ T-value } & \multicolumn{1}{c|}{ P-value } \\
\hline Dependent & Agrth & & & \\
\hline Inexpn_agric & 1.0109 & 0.3964 & 2.5502 & $0.0000^{* * *}$ \\
\hline vhat3 & 1.0000 & 0.3051 & 3.2800 & $0.0020^{* * *}$ \\
\hline _cons & -50.1575 & 16.5905 & -3.0200 & $0.0050^{* * *}$ \\
\hline Number of obs & $=$ & 38.0000 & & \\
\hline F(2,35) & $=$ & 14.7200 & & \\
\hline Prob $>$ F & $=$ & 0.0000 & & \\
\hline R-squared & $=$ & 0.4568 & & \\
\hline Adj R-squared & $=$ & 0.4258 & & \\
\hline Root MSE & $=$ & 4.2202 & & \\
\hline
\end{tabular}

Source: Computed from secondary data, 2018

Note: ${ }^{* *}$ significant at $1 \% ;{ }^{* *}$ significant at $5 \%$ and ${ }^{*}$ significant at $10 \%$.

According to Doherty (2007) Instrumental Variables are generally inconsistent if the instruments are correlated with the error term in the equation of interest; if weak instrument that are poor predictor in the first stage equation are selected. This may result in poor prediction of the endogenous explanatory variable by the instrument and the predicted value will have little variation. With equilibrium conditions imposed the two structural equation in the methodology were estimated, the output is presented in Table 6 which is the predicted values from the first stage IV regression and 2sls regression where urban population growth (urban_g) was used as an instrument. The idea is to decompose agrth into free and problematic component (that is, to eliminate the endogeneity problem) as well as looking at the relevance of instrument.

Instrumenting urban_g on Inexpn_agric it will be a valid instrument based on the following requirements which is sometimes described as instrument relevance: (a) it must be correlated with the endogenous explanatory variable that is, increases in urban_g has effect on government expenditure (b) instrument variable must not be correlated with the error term which implies that, increase in urban_g is uncorrelated with all other policy instruments variables not included in the model. From the result, the coefficient for urban_g is 0.4544 , statistically significant at $1 \%$ level, which means urban $\_g$ is related to government expenditure.

This satisfies one of the conditions of a valid instrument (instrument relevance). Additionally, the F-static in first stage is 49 which is greater than 10, the 'rule of thumb' this means the instrument is not weak. As stated earlier Instrumental variables are generally inconsistent if the instruments are correlated with the error term in the equation of interest; if weak instrument that are poor predictor in the first stage equation are selected. This may result in poor prediction of the endogenous explanatory variable by the instrument and the predicted value will have little variation (Doherty, 2007). Interestingly this is not the case. There is a "post-estimation" command called estat firststage that carries out this test of instrument validity as well as shown in Table 7 simply confirms the validity of the instrument with $(\mathrm{P}=0.000<0.01)$ which is not different from the output from the first stage regression. The $\mathrm{R}^{2}$ was 0.4300 . This means that $43 \%$ of the variation in agricultural growth is explained by government expenditure to agriculture (expn_agric), wage (wage_rate) and debt $\left(d e b t \_g d p\right)$. The F-statistics $(\mathrm{P}=0.000<0.01)$ was statistically significant at $1 \%$ indicating that all the variables included in the model jointly exert significant impact on agricultural growth. individually all the variables are significant at $1 \%$ with t-statistics $(\mathrm{P}=0.000<0.01)$ except wage_rate the wage rate was however significant from the estimates of DID model with impact factor of $1.75 \%$, this implies 
Table 6. First stage regression of Two stage least square estimation

\begin{tabular}{|c|c|c|c|c|}
\hline Variables & B-Coefficient & Standard error & z-value & P-value \\
\hline lnexpn_agric & lnexpn_agric & & & \\
\hline Inexdebt_gdp & 0.0148 & 0.0914 & 0.1600 & 0.8720 \\
\hline wag_rate & -0.2937 & 0.2848 & -1.0300 & 0.3100 \\
\hline urban_g & -0.4544 & 0.1005 & -4.5200 & $0.0000 * * *$ \\
\hline Inexpn_agric & 1.0411 & 0.1829 & 5.6900 & $0.0000 * * *$ \\
\hline _cons & -1.2573 & 2.8725 & -0.4400 & 0.6640 \\
\hline Number of obs & $=$ & 38.0000 & & \\
\hline $\mathrm{F}(4,33)$ & $=$ & 49.0200 & & \\
\hline Prob $>F$ & $=$ & 0.0000 & & \\
\hline R-squared & & 0.8560 & & \\
\hline Adj R-squared & $=$ & 0.8385 & & \\
\hline Root MSE & $=$ & 0.4004 & & \\
\hline Instrumental & Variables & (2SLS) & Regression & \\
\hline Dependent & Agrth & & & \\
\hline lnexpn_agric & 1.6663 & 0.1720 & 9.6877 & $0.0000 * * *$ \\
\hline Inexdebt_gdp & -2.2205 & 0.9520 & -2.3300 & $0.0200 * *$ \\
\hline wag_rate & 4.2724 & 2.9285 & 1.4600 & 0.1450 \\
\hline _cons & -123.7250 & 27.8591 & -4.4400 & $0.0000 * * *$ \\
\hline Number of obs & $=$ & 38.0000 & & \\
\hline Wald chi2(3) & $=$ & 29.6700 & & \\
\hline Prob > chi 2 & $=$ & 0.0000 & & \\
\hline R-squared & $=$ & 0.4300 & & \\
\hline Root MSE & $=$ & 4.1493 & & \\
\hline
\end{tabular}

Source: Computed from Field survey, 2018

Note: *** significant at $1 \%$; ${ }^{* *}$ significant at $5 \%$ and ${ }^{*}$ significant at $10 \%$.

Table 7. First-stage regression summary statistics

\begin{tabular}{|c|l|l|l|l|l|}
\hline \multicolumn{1}{|c|}{ Variable } & \multicolumn{1}{|c|}{ R Square } & $\begin{array}{c}\text { Adjusted } \\
\text { R Square }\end{array}$ & $\begin{array}{c}\text { Partial } \\
\text { R Square }\end{array}$ & \multicolumn{1}{|c|}{ F (2,33) } & P-value \\
\hline lnexpn_agric & 0.8560 & 0.8385 & 0.6523 & 30.9508 & $0.0000 * * *$ \\
\hline
\end{tabular}

Source: Computed from secondary data, 2018

Note: ${ }^{* \star *}$ significant at $1 \%$; ${ }^{* *}$ significant at $5 \%$ and ${ }^{*}$ significant at $10 \%$.

that wage rate is low and has not resulted in much impact on agricultural growth. This shows that the growth in agriculture was found to be linked to growth in all the variables included in the model.

The coefficient of government expenditure (lnexpn_agric) policy instrument was 1.663d.p and statistically significant at $1 \%$. This means that a proportionate rise in expenditure policy instrument resulted in $1.66 \%$ impact on agricultural growth ceteris paribus. The implication is that increasing expenditure on agriculture will have positive impact on agricultural growth. This goes to show that the 
recursive model must have biased the estimate downward and the standard error of 0.17 as compared to 0.21 in the recursive model implying that IVLS is more consistent and efficient too. The findings further showed that spending in agriculture is essential as a government instruments for promoting economic growth. This is in agreement with studies by (Sanyal, 2010; Fan et al, 2008; 2008; Ikpi, 1995). Although Akpan (2005) opined that no significant relationship exists among some components of government expenditures and economic growth in Nigeria. Amassoma, Nwosa, and Ajisafe (2011) concluded that agriculture expenditure had a significant impact on the economy. The coefficient of debt (Inexdebt_gdp) policy instrument was -2.221. This implies that a proportionate rise in debt policy instrument resulted in $2.22 \%$ impact on agricultural growth ceteris paribus and has standard error of -2.33 as compared to -2.19 in the DID model proving again the fact IVLS is more efficient.

Aregbeyen (2007) also found a positive and significant relationship between capital expenditure and economic growth but a negative relationship between recurrent expenditure and economic growth. Ogujiuba and Adeniyi (2004) examined the impact of government education expenditure on economic growth. Their result showed a statistically significant positive relationship between economic growth and recurrent expenditure on education, while capital expenditure was wrongly signed and not significant in its contributions. Loto (2011) studied the effects of government expenditures on security, health, education, transport, communication, and agriculture on the economy using error correction test and obtained similar results. Under-funding of the recurrent budget has become an increasing problem over recent years and has resulted in capital investments being made without due regard to the recurrent costs required properly to service these investments (Ammani \& Aliyu, 2012). Low government expenditure must have increased the cost of equipments and implements hence high cost of good the high price of agricultural products in Nigeria. Increased investment will attract the demand for labor and stimulate productivity hence growth in agriculture. The implication is that increasing expenditure on agriculture will have positive impact on agricultural growth. According to Fosu (2009) government expenditures on agriculture affect various determinants of agricultural growth. Thus increased public expenditure means that the basic infrastructures e.g. roads, electricity, irrigation and drainage as well as research and development (R\&D) may have received adequate attention. The coefficient of debt (Inexdebt_gdp) policy instrument was -2.221 . This implies that a proportionate rise in debt policy instrument resulted in $2.22 \%$ impact on agricultural growth ceteris paribus and has standard error of -2.33 as compared to -2.19 in the DID model proving again the fact IVLS is more efficient.

\subsection{Diagnostics Test}

Ramsey (1969) regression specification-error test (RESET) for omitted variables, Table 8. estat ovtest performs two versions of the test. This test amounts to fitting $y=x b+z t+u$ and then testing $t=0$. If option rhs is not specified, powers of the fitted values are used for $\mathrm{z}$. If rhs is specified, powers of the individual elements of $\mathrm{x}$ are used.

Table 8. Ramsey RESET test using powers of the fitted values of agrth

\begin{tabular}{|c|l|l|l|}
\hline \multicolumn{1}{|c|}{ F-value } & \multicolumn{1}{|c|}{ Df } & \multicolumn{1}{c|}{ Prob $>$ F } & \multicolumn{1}{c|}{ Decision } \\
\hline 0.296 & 3 & 0.133 & Not rejected \\
\hline
\end{tabular}

Ho: model has no omitted variables

Source: Computed from secondary data, 2018

Note: ${ }^{* * *}$ significant at $1 \% ;{ }^{* *}$ significant at $5 \%$ and ${ }^{*}$ significant at $10 \%$. 


\subsubsection{Model Specification Error Test}

From the result $(\mathrm{P}=0.133>0.1)$ so the null hypothesis is not rejected. Diagnostic tests carried out above indicate that estimated models have correct functional form, there is no omitted variable and no irrelevant variable is included. The implication is that the model for monetary policy instruments and agricultural growth is correctly specified and no serious error of misspecification. It should be noted however that this test is a limited tool to detect specification errors just as any other tools. This is because RESET loses statistical power rapidly as powers of estimated y are added.

\subsubsection{Autocorrelation and Multicollinearity}

Multicollinearity is not a problem among the variables because Stata does this automatically by removing perfect collinearity. The command estat bgodfrey in STATA performs three versions of the Breusch-Pagan (1979) and Cook-Weisberg (1983) test for autocorrelation. The result of BreuschGodfrey LM test for Autocorrelation is shown in Table 9.

H0: no serial correlation

The result from Table 9 indicated $(\mathrm{P}=0.2233>0.1)$. The result showed that the model has no serial correlation since the null hypothesis of no-serial correlation is not rejected at all levels of significance.

Table 9. Breusch-Godfrey LM test for Autocorrelation

\begin{tabular}{|c|l|l|l|l|}
\hline \multicolumn{1}{|c|}{ Lags(1) } & \multicolumn{1}{c|}{ Chi2 } & \multicolumn{1}{c|}{ df } & \multicolumn{1}{c|}{ P>chi2 } & Decision \\
\hline 1.396 & 1.483 & 1 & 0.2233 & Not rejected \\
\hline
\end{tabular}

\subsubsection{Heteroscadasticity}

The result of Breusch-Pagan / Cook-Weisberg test for heteroskedasticity is presented in Table 10.

The result from Table 10 indicated $(\mathrm{P}=0.3251>0.1)$ therefore the null hypothesis of constant variance is not rejected at all levels of significant. According to Adkins and Hill (2008) the least square estimator can be used to estimate linear model even when the errors are heteroscadastic because the estimates will still be unbiased and consistent especially with time series data. The only problem will be that the variance-covariance matrix is not precise. However the use of robust variance-covariance estimator (VCE) in stata corrected the problem.

Table 10. Breusch-Pagan / Cook-Weisberg test for heteroskedasticity

\begin{tabular}{|l|l|l|l|l|}
\hline \multicolumn{1}{|c|}{ Variables: } & \multicolumn{1}{c|}{ Chi2 } & \multicolumn{1}{c|}{ df } & \multicolumn{1}{c|}{ P>chi2 } & \multicolumn{1}{c|}{ Decision } \\
\hline fitted values of agrth & 1.65 & 1 & 0.3251 & Not rejected \\
\hline
\end{tabular}

Ho: Constant variance

Source: Computed from secondary data, 2018

Note: ${ }^{* * *}$ significant at $1 \%$; ** significant at $5 \%$ and ${ }^{*}$ significant at $10 \%$

\section{CONCLUSION}

The findings revealed that agricultural growth adjusted fairly to the dynamics of macroeconomic policy instruments in Nigeria. The instantaneous growth rate for agricultural output was 5.9\% while the compound rate of growth amounted to $6.08 \%$. A rise in expenditure policy instrument 
resulted in $1.66 \%$ impact on agricultural growth. A proportionate increased debt resulted in less than proportionate decrease of $-0.32 \%$ decreased in agricultural growth. Thus, Expenditure in agriculture is needed in generating the necessary level of investment, both public and private, in technology and infrastructure to facilitate agricultural as well as economic growth in Nigeria while increased debt profile will retard growth. The study recommended increased government expenditure to agricultural sector, education, investing in human capital development through budgetary allocations and intervention funds for increased productivity thereby enhancing and promoting growth in the process while policy makers should desist from increasing the debt profile as it has negative effect on the Nigerian economy. Alternatively debt acquired should be project specific with zero interest rate. It should be noted however that rather than examining the impact of fiscal instrument alone, a more rewarding course of action would be to combine the impact of both monetary and fiscal policy instruments on agricultural growth. To gain a clearer understanding of the full impact of unfavorable policy instruments, it is important to understand what other unobserved factors are and how they undermine the impact of the policy. Previous research has pointed to the joint influence of demand and supply side policies and agricultural specific policy instruments e.g. agricultural expenditures policy instruments, agricultural subsidies, taxes and tariff, quotas, irrigation policies etc inclusive of both fiscal and monetary on agricultural growth. These research findings highlight the importance of creating a favorable macroeconomic environment to support agricultural growth. While increased attention, investment, and research has been directed toward agricultural growth and development, the special contribution of this paper and the underlying research is in relating the direct impact of macroeconomic policy instruments on agricultural growth without sacrificing other economic policy objectives and effectiveness. 


\section{REFERENCES}

Abu, N., \& Usman, A. (2010). Government expenditure and economic growth in Nigeria, 1970-2008: A disaggregate analysis. Business and Economics Journal, 1-18.

Adekeye, F. (2008). The way out of the decay. Tell (Nigeria) Magazine, 120. http://www.desd.org.desdcd/africa. html

Adubi, A. A., \& Okunmadewa, F. (1999). Price, exchange rate volatility and Nigeria's agricultural trade flows: A dynamic analysis. National Centre for Economic Management and Administration (NCEMA) lbadan, Nigeria ERC Research Paper 87.

Agbonkhese, A. O., \& Asekome, M. O. (2014). Impact of public expenditure on the Growth of Nigerian economy. European Scientific Journal, 10(28).

Agénor, P. (1995). Output, devaluation and the real exchange rate in Developing Countries. Weltwintschaftliches Archiv, 127(1), 18-41.

Agosin, M. R., \& Mayer, R. (2000). Foreign investment in developing countries. does it crowd in domestic investment? UNCTAD/OSG/DP.

Agu, S., Idike, A., Okwor, I., \& Ugwunta, D. (2014). Fiscal policy and economic growth in Nigeria: Emphasis on various components of public expenditure. Singaporean Journal of Business Economics and Management Studies, 2(12), 37-57. doi:10.12816/0006800

Ajayi, S. I. (1995). Capital flight \& external debt in Nigeria. Research Paper 35, African Economic Research Consortium (AERC), Nairobi, Kenya.

Ajisafe, R. A. \& Folorunsho, B. A. (2002). The relative effectiveness of fiscal and monetary policy in macroeconomic management in Nigeria. The African Economic and Business Review, 3(1).

Akpan, M. I. (2005). Government expenditure and economic growth in Nigeria: A Disaggregated Approach. CBN Economic and Financial Review, 43(1).

Amassoma, D., Nwosa, P., \& Ajisafe, R. (2011). Components of government spending and economic growth in Nigeria: An Error Correction Model. Journal of Economics and Sustainable Development, 2(4), 34-59.

Ammani \& Aliyu, A. (2012). An Investigation in to the relationship between agricultural production and formal credit supply in Nigeria. International Journal of Agriculture and Forestry, 2, 46-52. doi:10.5923/j. ijaf.20120201.08

Aregbeyen, O. (2017). Public expenditure and economic growth. African Journal of Economic Policy, 1(1). Advance online publication. doi:10.4314/ajep.v14i1.44191

Baum, C. F. (2006). Introduction to modern econometrics using stata. STATA Press.

Borensztein, E., DeGregorio, J., \& Lee, J. (1998). How Does foreign direct investment affect economic growth? Journal of International Economics, 45(1), 115-135. doi:10.1016/S0022-1996(97)00033-0

Calvo, G., \& Reinhart, C. (2002). Fear of floating. The Quarterly Journal of Economics, 117(2), 379-408. doi:10.1162/003355302753650274

Central Bank of Nigeria CBN \& NBS. (2018). Contemporary economic policy issues in Nigeria. Author.

Chenery, H. B. (1958). Development policies and programmes: Policy Instruments and development alternatives. Economic Bulletin for West Latin America, 3(1), 55-60.

Chimobi, O. P., \& Uche, U. C. (2010). Export, domestic demand and economic growth in Nigeria: Granger causality analysis. European Journal of Soil Science, 13(2), 211-218.

Dayo P., Ephraim N., John, P., \& Omobowale, A. O. (2009). Constraints to Increasing Agricultural Productivity in Nigeria: A Review. Nigeria Strategy Support Program (NSSP). Background Paper, No. NSSP 006.

Dougherty, C. (2007). Introduction to econometrics. Oxford University Press. 
Eboh, E., Oduh, M., \& Ujah, O. (2012). Drivers and sustainability of agricultural growth in Nigeria. African Institute for Applied Economics AIAE, Research Paper 8.

Ellis, F. (1996). Agricultural Policies in Developing Countries. Cambridge University Press.

Everett, T., Ishwaran, M., Ansaloni, G.P. \& Rubin, A. (2010). Economic Growth and the Environment. Econsgrowth Defra Evidence and Analysis. Series Paper 2.

Eze, C., Lemchi, J., Ugochukwu, A., Eze, V. C., Awulonu, O., \& Okon, X. (2010). Agricultural financing policies and rural development in Nigeria. The 84th Annual Conference of the Agricultural Economics Society.

Fan, S., \& Rao, N. (2003). Public spending in developing countries: Trends, determination, and impact. EPTD Discussion Paper No 99, International Food Policy Research Institute, Washington, DC.

Fan, S., Yu, B., \& Saurkar, A. (2008). Public spending in developing countries: Trends, composition, and changes. In Public Expenditure, Growth, and Poverty in Developing Countries: Issues, Methods, and Findings. Johns Hopkins University Press.

FMARD. (2016). The agriculture promotion policy (2016 - 2020) building on the successes of the ata, closing key gaps. Policy and Strategy Document.

Folster, S., \& Henrekson, M. (1997). Growth and the public sector: A critique of the critics. The Research institute of industrial economics. Working paper No. 492.

Folster, S., \& Henrekson, M. (2000). Growth effects of government expenditure and taxation in rich countries. European Economic Review, (45), 8.

Fosu, K. Y. (2015). Determinants and effectiveness of government expenditure policy in ghana's agricultural sector. Department Agricultural Economics Ghana.

Gujarati, D., \& Porter, D. (2009). Basic Econometrics (4th ed.). McGraw-Hill.

Hartwich, F., Kormawa, P., Ibrahim, D., Bisallah, B., Odufote, B.O., \& Polycarp, I. M. (2010). Unleashing agricultural development in Nigeria through Value Chain Financing. Draft Report. UNIDO; CBN and Bank of Industry, Nigeria.

Ikpi, A. E. (1995). Policy relevance of research for sustainable development in Nigeria's Agriculture. Proceedings of a workshop on Nigeria's Agricultural Research, Policy, Planning and Plan Implementation Experience and Relevance to Development.

Iloeje, N. P. (2001). A new geography of Nigeria (New Revised Edition). Longman Nigeria PLC.

Isedu, M. O. (2002). Nigeria Financial Management. Benin: Best Printers.

Loto, M. A. (2011). Impact of government sectoral expenditure on economic growth. Journal of Economics and international Finance, 3(11), 646-652.

Manyong, V. M., Ikpi, A., Olayemi, J. K., Yusuf, S. A., Omonona, B. T., Okoruwa, V., \& Idachaba, F. S. (2005). Agriculture in Nigeria: Identifying opportunities for increased commercialization and investment. International Institute of Tropical Agriculture. IITA.

Maskus, K. E. (1986). Exchange rate risks and U.S. trade: A sectoral analysis. Federal Reserve Bank of Kansas City. Econ. Rev.

Obansa, S. A. J., \& Maduekwe, I. M. (2013). Agriculture financing and economic growth in Nigeria. European Scientific Journal, (1), 1-37.

Ofanson, E. J. (2007). Public sector finance. Bobpeco Publishers.

Ogujiuba, K., \& Adeniyi, A. (2004). Is trade openness valid for Nigeria's long-run growth: A co-integration approach. Journal of International Trade, 4(1), 44-52.

Olomola, A. S. (2007). Competitive Commercial Agriculture in Africa Study (CCAA): Nigeria Case Study. Final Report submitted to the Canadian International Development Agency (CIDA) and the World Bank. 
Oluwatobi, S. O., \& Ogunrinola, I. O. (2011). Government expenditure on human capital development: Implications for economic growth in Nigeria. Journal of Sustainable Development, 4(3), 72-80. doi:10.5539/ jsd.v4n3p72

Osagie, E. (1985). An operational econometric model of the Nigerian economy: Some preliminary estimates. Ife Social. Scientific Review (Singapore), (2), 149-165.

Pingali, P. (2006). Agricultural growth and economic development: A view through the globalization lens. Presidential Address to the 26th International Conference of Agricultural Economists, Gold Coast, Australia.

Sachs, J. (1997). Nature, nurture and growth. Economist, 14, 9-27.

Sanyal, P., \& Babu, S. (2010). Policy benchmarking and tracking the Agricultural Policy Environment in Nigeria. Nigeria Strategy Support Program (NSSP). Report No. NSSP, 005, 23.

United Nations Conference on Trade and Development UNCTAD. (2016). The path to graduation and beyond: Making the most of the process. The Least Developed Countries Report (2016).

World Bank. (2007). Nigeria-A fiscal agenda for change: Public expenditure management and Financial accountability review. In Poverty Reduction and Economic Management, Africa Region. World Bank. 